\title{
24. Mapping metallic contamination of soils in the Lower Foyle catchment
}

\author{
Solveigh Lass-Evans ${ }^{\mathrm{I}}$
}

How to cite this chapter: Lass-Evans, S., 2016 'Mapping metallic contamination of soils in the Lower Foyle catchment' in M.E. Young (ed.), Unearthed: impacts of the Tellus surveys of the north of Ireland. Dublin. Royal Irish Academy.

DOI:10.3318/ 978-1-908996-88-6.ch24
Using the Tellus and Tellus Border geochemistry data, the distribution of metals in topsoils in and around Derry-Londonderry has been mapped and assessed. The concentrations of metals have been compared with the UK Environment Agency's Soil Guideline Values (SGVs). Of 763 samples analysed, only 11 samples exceed the SGV for arsenic and two for that of cadmium. Of these 13 sites, only two were within an urban area. Concentrations of metal in the rural sub-catchments appear to be mainly determined by the underlying geology.

Using a geographic information system (GIS) and multi-element plots (spidergrams) for analysis, the geological background was modelled at a sub-catchment scale in order to determine whether high soil metal concentrations were of natural origin or a consequence of anthropogenic activities. The level of enrichment due to contamination was calculated for 12 metals and metalloids. In the urban area of Derry-Londonderry, levels of arsenic, cadmium and seven other elements are slightly enhanced due to anthropogenic activities. However, as the enrichment factors do not exceed a factor of 3 these enhancements are classified as minor. Possible modern and historic sources of contamination are likely to be buildings, households and waste disposal, hospitals and medical facilities, surface run-off from road traffic, manufacturing industries, coal disposal and sewage works.

\section{INTRODUCTION}

It is self-evident that we rely on clean soil for safely growing crops, grazing livestock and outdoor recreation, so it is important that we monitor it for potentially harmful elements. This chapter illustrates how we can use the results of the Tellus and Tellus Border geochemical survey programmes to map the extent and origin of both naturally occurring and anthropogenic metals in a selected area, the cross-border lower catchment of the River Foyle.

Many city environments have been affected by urban and industrial processes over a long timespan. As a result, various substances, such as heavy metals, have often been

\footnotetext{
${ }^{\mathrm{I}}$ British Geological Survey, Edinburgh.
} 
released into the environment. Exposure to high concentrations of heavy metals can have toxic effects, so their occurrence in the environment could have long-term implications for ecosystems and human health. Human exposure to metals may arise through inhalation of wind-blown dust, direct ingestion of soil or consumption of locally grown vegetables. Environmental information, such as that provided by the Tellus Projects, helps to identify this hazard and to reduce potential risks to people, animals and the environment.

In order to assess the impact of anthropogenic activities on soil geochemistry, we need to understand the contemporary baseline chemistry of the natural environment. Important terms in environmental geochemistry are the geochemical baseline and the geochemical background. According to the Forum of European Geological Surveys (FOREGS) Geochemistry Working Group, a geochemical baseline can be defined as the concentration at a specific point in time of a chemical parameter (element, species or compound) in a sample of geological material. It is a fluctuating surface rather than a given value (Johnson and Ander, 2008). A geochemical baseline reports the chemical state of the surface environment, with no interpretation of the data.

In environmental geochemistry, the geochemical or natural background can be defined as the relative measure to distinguish between natural element or compound concentrations and anthropogenically influenced concentrations in real sample collectives (Matschullat et al., 2000). The background may comprise many contributing geochemical populations (caused by compositional variations in underlying parental material) and the anthropogenic contribution, which is likely to be from multiple sources (Johnson and Demetriades, 2011). A detailed review of the numerous studies on approaches to determine background concentrations is beyond the scope of this work, but detailed reviews are given by Matschullat et al. (2000) and Reimann and Garrett (2005). More recently, the term Normal Background Concentrations (NBCs) has been used, as defined by BS EN ISO 19258:2011 (British Standards Institution, 2011), which includes both the natural and diffuse anthropogenic contribution to an element concentration in the soil, but excludes point contamination inputs. In studies such as those of Johnson et al. (2012) and Ander et al. (2013), NBCs were attributed to different regions of the country, where readily distinguishable factors (such as the underlying parent material, metalliferous mineralisation with associated mining activities and the urban environment) control the concentration of an element in soils. The areas showing the most significantly elevated element concentrations in soils were identified as contaminant domains.

This study presents a detailed approach to characterising the natural background and thus to determining the anthropogenic contribution to overall metal concentrations. The aim of the project was to assess the chemical quality of soils in the lower River Foyle catchment, including urban Derry-Londonderry and the surrounding rural cross-border area, in order to identify sub-catchments where anthropogenic impacts may have had a detrimental effect on land quality. In particular, the project has assessed the influence of the urban area of Derry-Londonderry on the soil environment. In order to determine whether 
high soil metal concentrations were of natural (geogenic) origin or resulted from anthropogenic activities, the 'geological background' was modelled by taking account of the different geological lithologies of the 31 sub-catchments of the lower River Foyle. Using a GIS and multi-element diagrams, soil quality in the study areas was assessed, and degrees of metal enrichment above the natural geological background and attributed to anthropogenic impacts were quantified. The methodology demonstrated here should contribute to future environmental protection and catchment management strategies.

\section{THE REgUlATORY CONTEXT}

\section{Source-pathway-receptor model}

In the UK, the environmental quality of land is commonly assessed using the Contaminated Land Regulations, which enforce Part IIa of the Environmental Protection Act (1990). Contaminated land is defined by identifying pollutant linkages between a contaminant (a substance that is in, on or under the land and has the potential to cause harm), a pathway (a route by which a receptor can be exposed to, or affected by, a contaminant) and a receptor (something that could be adversely affected by a contaminant, such as people) (DEFRA and Environment Agency, 2004). Each of these elements can exist independently, but together they create a potential risk. All three components must be present for a site to be defined as contaminated land.

\section{The CLEA framework}

Under the Contaminated Land Exposure Assessment (CLEA) framework, the Environment Agency (EA), an executive non-departmental public body sponsored by the UK Department for Environment, Food and Rural Affairs (DEFRA), has developed a risk assessment tool for human exposure to contaminated soils. Generic SGVs have been developed for quantitative risk assessment of land contamination (DEFRA and Environment Agency, 2004). These can be used for initial assessment of human health risks arising from long-term and on-site exposure to chemical contamination in soil. They represent 'trigger values' - indicators that soil concentrations above this level may pose 'a possibility of significant harm to human health' (DEFRA, 2008). They do not represent the threshold at which a 'significant possibility of significant harm' could occur but they present a useful starting point for further investigation (Environment Agency, 2009a, 2009b). In the Republic of Ireland the Environmental Protection Agency (EPA) supports the application of the UK EA approach to risk assessment and contaminated land (Doak, 2004). Some important SGVs are shown in Table 24.1. 


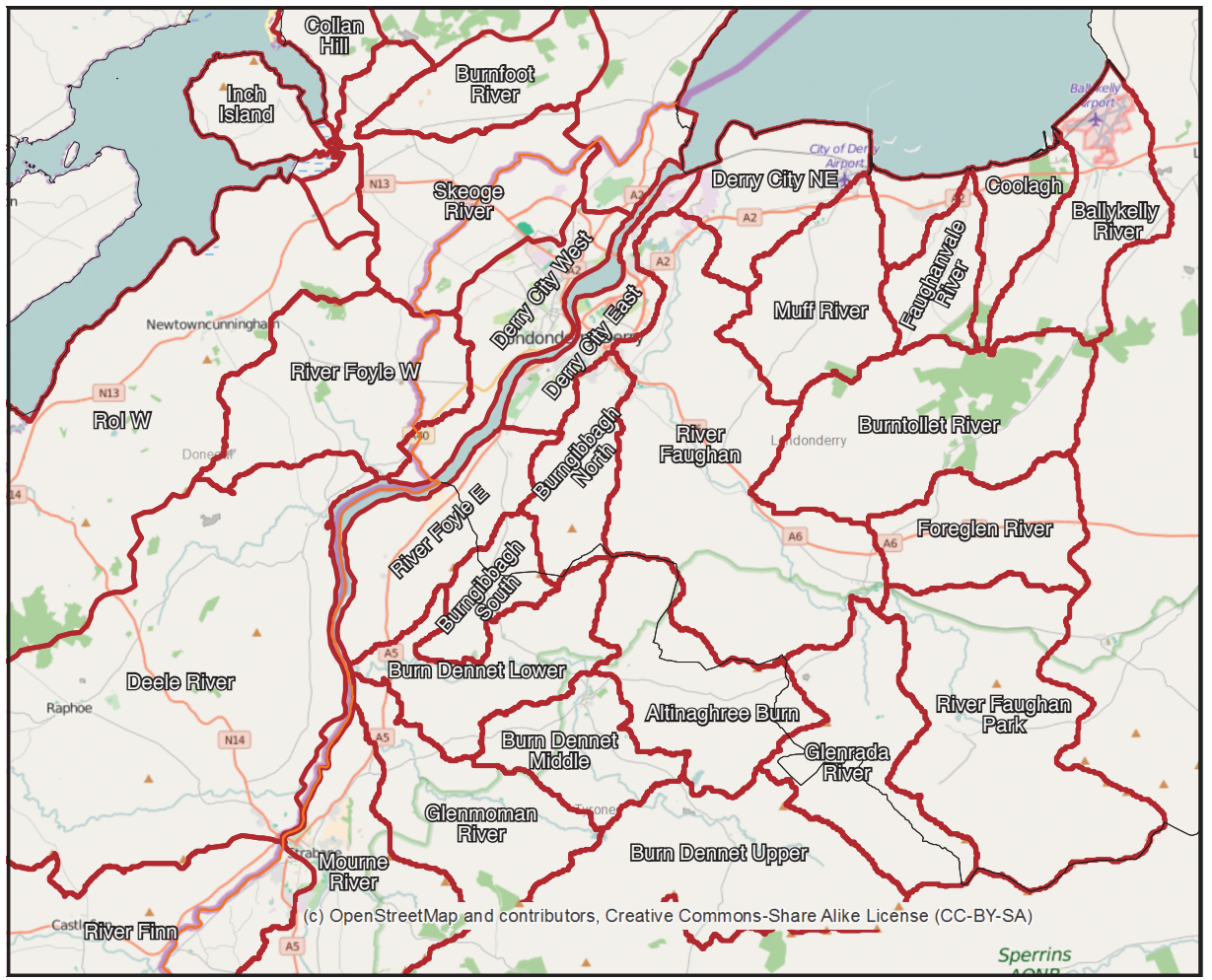

TABLE 24.I. CLEA GENERIC SGVS FOR SPECIFIC LAND USE TYPES (IN MG KG ${ }^{-1}$ ) (ENVIRONMENT AgENCY, 2009B)

\begin{tabular}{c|c|c|c|c|c} 
Land use & $\mathrm{As}$ & $\mathrm{Cd}$ & $\mathrm{Hg}$ & $\mathrm{Ni}$ & $\mathrm{Se}$ \\
\hline Allotment & 43 & 1.8 & 80 & 230 & 350 \\
\hline Residential & 32 & 10 & 170 & 130 & 120 \\
\hline Commercial & 640 & 230 & 3600 & 1800 & 13,000
\end{tabular}

\section{TOPOGRAPHY, GEOLOGY AND SOILS DATA}

The project modelled the geological background of 31 sub-catchments (Fig. 24.1) to distinguish high metal element concentrations of natural origin from those of anthropogenic origin by:

1. mapping the spatial distribution of soil metal in the study area;

2. assessing soil quality with respect to soil quality guidelines;

3. modelling the naturally occurring (geogenic) chemical background values of the major geological units on a sub-catchment scale;

4. distinguishing natural from anthropogenic metal concentrations and thus determining the extent of the anthropogenic contribution.

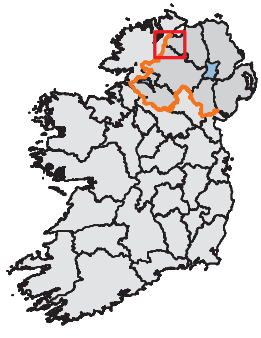

Sub-catchments

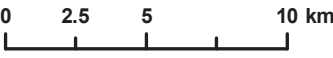

Figure 24.1. Study area sub-catchments. 
Sample Locations for Tellus and Tellus Border Geochemistry Programmes

\section{Surface 'A' Soils Depth $5-20 \mathrm{~cm}$ \\ Rural (Tellus) \\ Rural (Tellus Border) \\ Urban (Tellus)}
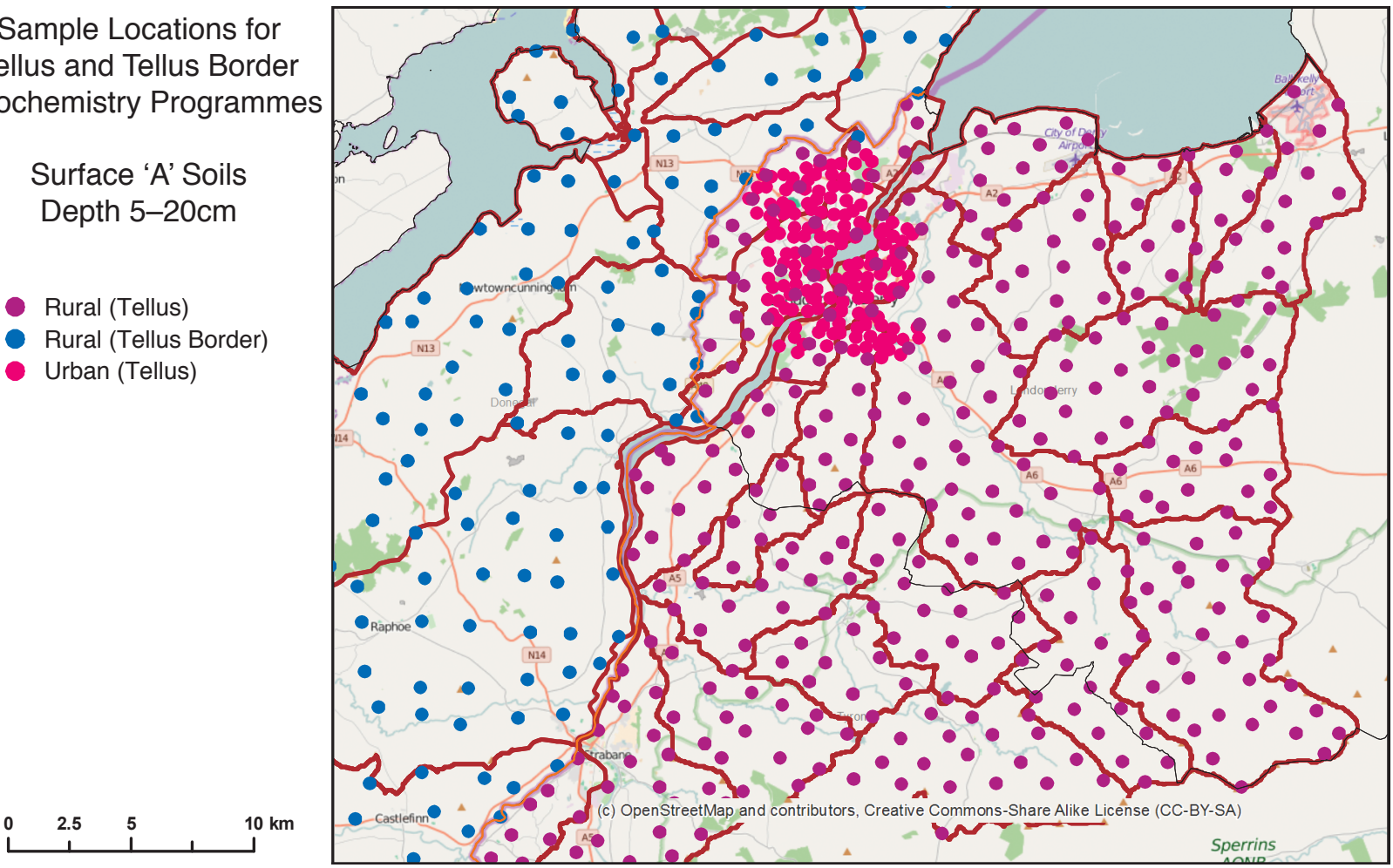

Figure 24.2. Map of the Derry-Londonderry study area showing the Tellus and

Tellus Border soil sample locations.

\section{Tellus and Tellus Border soil geochemistry data SeTS}

The study was based on three topsoil geochemistry data sets (Fig. 24.2):

- 468 samples, one site per $2 \mathrm{~km}^{2}$, collected 2004-6 (rural surroundings of DerryLondonderry, Tellus Project);

- 162 samples, four sites per $\mathrm{km}^{2}$, collected 2004-6 (urban Derry-Londonderry, Tellus Project);

- 133 samples, one site per $4 \mathrm{~km}^{2}$, collected 2011-12 (rural surroundings of DerryLondonderry, west of Lough Foyle, Tellus Border Project).

These sampling surveys and analysis are described by Young et al. (Chapter 3, this volume). The urban samples were collected as part of the British Geological Survey's programme of mapping major British cities (Johnson and Ander, 2008). Derry-Londonderry was sampled as part of a project that included a survey of Belfast, described by Knights (2007). More recently, an urban geochemical survey of Dublin has been undertaken (Glennon et al., 2014); although not part of the Tellus Border Project, these results provide an interesting comparison with those of Belfast and Derry-Londonderry. 


\section{TABle 24.2. Possible Current Sources of ANTHropogenic CONTAMINATION IN SELECTED SUB-CATCHMENTS}

\begin{tabular}{|c|c|c|c|c|}
\hline Sub-catchment & $\begin{array}{c}\text { Possible } \\
\text { anthropogenic } \\
\text { contamination } \\
\text { sources }\end{array}$ & $\begin{array}{c}\text { No. } \\
\text { samples } \\
\text { (observed) }\end{array}$ & $\begin{array}{l}\text { No. } \\
\text { samples } \\
\text { (model) }\end{array}$ & $\begin{array}{l}\text { Elements with } \\
\text { higher values in } \\
\text { observed signature } \\
\text { compared to } \\
\text { geological } \\
\text { background }\end{array}$ \\
\hline $\begin{array}{l}\text { Burngibbagh } \\
\text { North }\end{array}$ & $\begin{array}{l}\text { Urban; industrial } \\
\text { estate, railway, road }\end{array}$ & 20 & 13 & $\begin{array}{c}\mathrm{Cu}, \mathrm{Ni}, \mathrm{Pb}, \mathrm{Sb}, \mathrm{Sn} \\
\mathrm{Be}, \mathrm{Bi}\end{array}$ \\
\hline $\begin{array}{l}\text { Burngibbagh } \\
\text { South }\end{array}$ & $\begin{array}{l}\text { Close to sewage } \\
\text { works but high } \\
\text { organic content }\end{array}$ & 7 & 6 & $\mathrm{Co}, \mathrm{Ni}$ \\
\hline Derry City East & $\begin{array}{c}\text { Urban; } \\
\text { construction site, } \\
\text { brownfield site, } \\
\text { sewage works; road }\end{array}$ & 50 & 8 & $\begin{array}{c}\mathrm{Ag}, \mathrm{As}, \mathrm{Cd}, \mathrm{Co}, \mathrm{Cu}, \\
\mathrm{Hg}, \mathrm{Ni}, \mathrm{Pb}, \mathrm{Sb}, \mathrm{Sn}, \\
\text { Be, Bi, Mo }\end{array}$ \\
\hline Derry City NW & Urban; road & 21 & 14 & $\mathrm{~Pb}, \mathrm{Sn}$ \\
\hline Derry City West & $\begin{array}{l}\text { Urban; industrial } \\
\text { estate; coal depot; } \\
\text { road }\end{array}$ & 70 & 16 & $\begin{array}{c}\mathrm{Ag}, \mathrm{Cu}, \mathrm{Hg}, \mathrm{Ni}, \mathrm{Pb}, \\
\mathrm{Sb}, \mathrm{Sn}, \mathrm{Zn}, \mathrm{Be}, \mathrm{Bi} \\
\text { Mo }\end{array}$ \\
\hline Mourne River & Urban; sewage & 20 & 19 & $\mathrm{Cu}, \mathrm{Hg}, \mathrm{Pb}, \mathrm{Sn}$ \\
\hline Skeoge River & $\begin{array}{c}\text { Urban; road; } \\
\text { sewage; soil dump? }\end{array}$ & 50 & 29 & $\begin{array}{l}\mathrm{Ag}, \mathrm{As}, \mathrm{Cu}, \mathrm{Hg}, \mathrm{Ni}, \\
\mathrm{Pb}, \mathrm{Sb}, \mathrm{Sn}, \mathrm{Bi}, \mathrm{Mo}\end{array}$ \\
\hline
\end{tabular}

\section{The Lower Foyle study area}

The project studied an area of approximately $1050 \mathrm{~km}^{2}$, extending from Strabane and the Sperrin Mountains in the south to Derry-Londonderry and the surrounding rural crossborder area in the north. Apart from a few towns, the area is largely rural. Historically, the textile industry was prominent here, notably shirt making, which started in 1831. For a time Derry-Londonderry was the most prolific centre of this industry in the UK and exported all over the world, with a peak in the 1920s.

\section{Geology and soil type}

Figure 24.3 summarises the bedrock geology of the area (GSNI, 1997), which has been described by Cooper and Johnston (2004). Most of the study area is underlain by mid- 


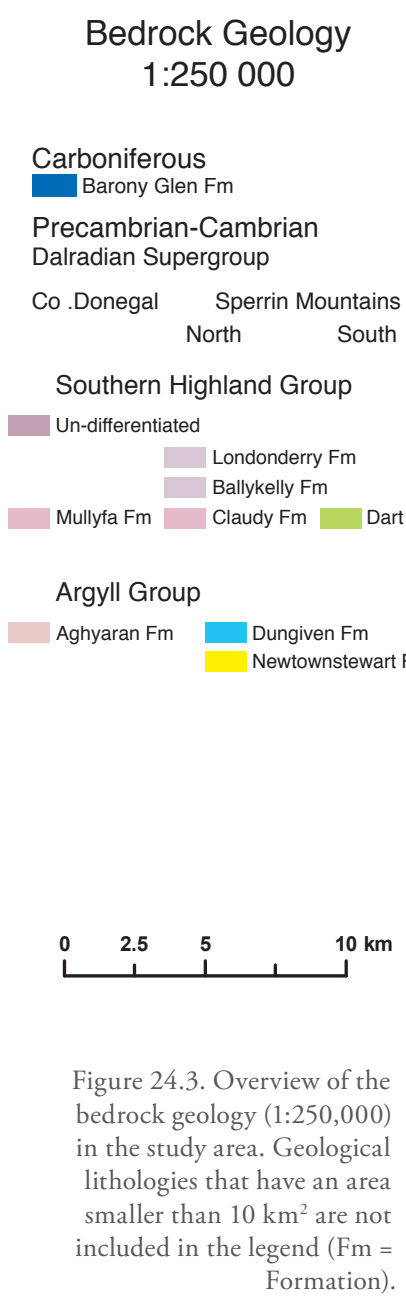

\section{Bedrock Geology $1: 250000$}

\section{Carboniferous \\ Barony Glen Fm}

Precambrian-Cambrian Dalradian Supergroup

Co .Donegal

Sperrin Mountains
North South

Southern Highland Group

Un-differentiated

Mullyfa Fm $\quad$ Ballykelly $\mathrm{Fm}$ Dart Fm

Argyll Group

Aghyaran Fm

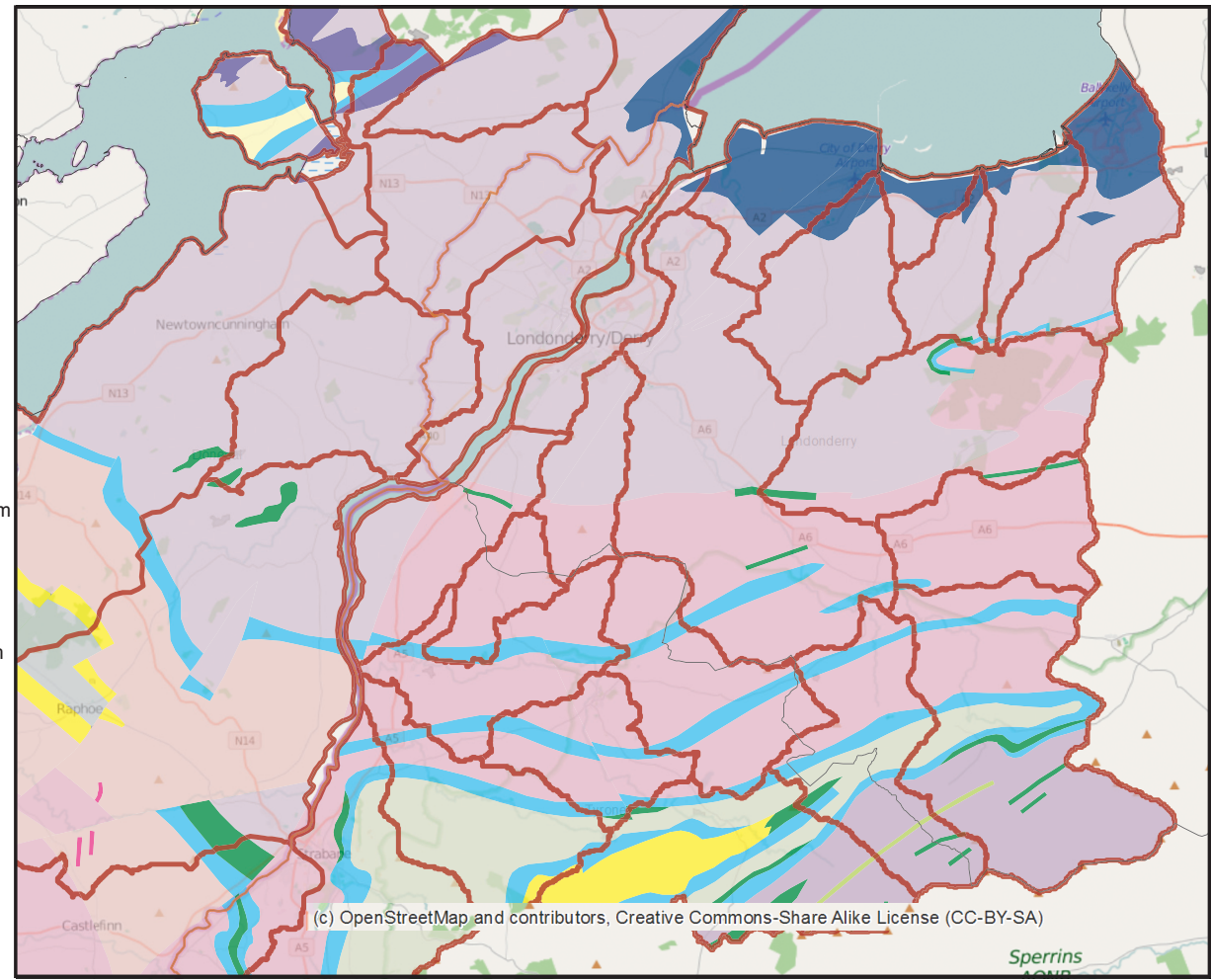

to late Neoproterozoic rocks of the Dalradian Supergroup. These predominantly clastic marine sediments are divided into the Argyll Group and the Southern Highland Group.

The oldest Dalradian rocks (Newtownstewart Formation) in the study area occur in the Sperrin Mountains and consist of grey, thickly bedded psammite with thin pelite interbeds. As the highest formation of the Argyll Group, the Dungiven Limestone Formation occurs in the southern part of the study area and consists of limestone with metabasite intrusions, pillow lavas and volcanoclastic sediments.

The Southern Highland Group consists mainly of turbidites. The Dart Formation in the southern Sperrin Mountains comprises amphibolite, overlain by volcanoclastic semipelite. The lithostratigraphy of the Southern Highland Group in the north Sperrin Mountains and north County Londonderry is divided into the Claudy Formation, the Ballykelly Formation and the Londonderry Formation. The oldest, the Claudy Formation, consists of psammite units with semipelite and two limestone units as markers. The succeeding Ballykelly Formation consists mainly of meta-arenites with a Limestone Member at the base of the formation. East Derry-Londonderry is underlain by the succeeding Londonderry Formation, consisting of meta-arenite and pelite.

The Dalradian rocks in County Donegal in the western part of the study area are classified as the Aghyaran Formation, which is equivalent to the Dungiven Limestone Formation in the Sperrin Mountains, consisting of interbedded meta-limestone and meta-dolomite 


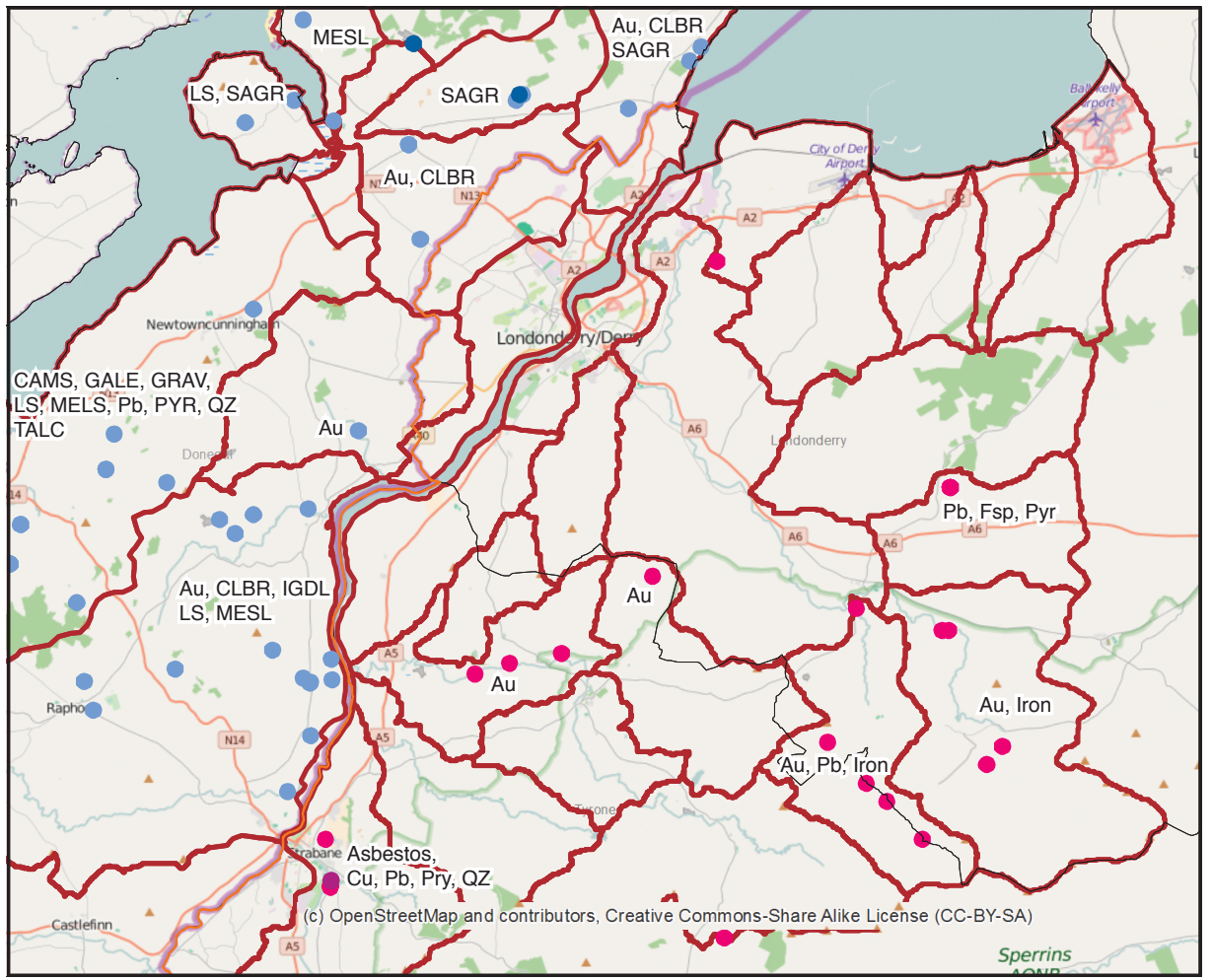

with quartzite and associated psammite. The Mullyfa Formation, consisting mainly of bedded psammites, occurs at the base of the Southern Highland Group. The upper Dalradian of County Donegal is undivided and consists of psammite and pelite.

Carboniferous-age rocks occur in the study area at the coast east of Derry-Londonderry. The Barony Glen Formation, the upper section of the Roe Valley Group, consists of mudstone, limestone, siltstone and sandstone (Mitchell, 2004).

\section{Soil types}

As described by Cruickshank (1997), the soil type in the rural areas west and east of Derry-Londonderry is gleyed soils, developed on mica-schist and mica-schist till with brown earth on the slopes of the uplands. Freely draining and steep-sided gravel formations fill the Sperrin valleys, ranging from brown earths to peat podzols. Blanket peat covers the gently sloping summits and plateau surfaces of the North Sperrin Mountains. Reclaimed marine alluvium occurs at the coast, north-east of Derry-Londonderry.

\section{Catchments and water courses}

River and stream catchment boundaries have been established by the Northern Ireland Environment Agency (NIEA) and the EPA (Fig. 24.1). For the purpose of this study, some sub-catchments have been merged and simplified. The locations of water courses were
Mineral Occurrences and Mining Locations

Adits and Shafts (NI)

Mineral Occurences (NI)

Mineral Occurrences (Rol)

Quarries (Rol)

Sub-catchments

$\mathrm{Au}=$ gold

$\mathrm{Cu}=$ copper

CAMS = camstone

CLBR $=$ clay, brick

Fsp $=$ feldspar

GALE = galena

GRAV $=$ gravel

IGDL = greenstone

$\mathrm{LS}=$ limestone

MESL $=$ slate

$\mathrm{Pb}=$ lead

Pry = pyrite

$\mathrm{Qz}=$ quartz

SAGL $=$ sand, gravel

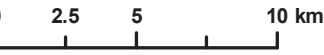

Figure 24.4. Mineral occurrences and mining locations according to GSNI and GSI records (Legg et al., 1985). 
provided by Land and Property Services (Northern Ireland) and the EPA (Republic of Ireland).

\section{Mining locations and mineral occurrences}

Figure 24.4 shows the occurrences of mineral locations, as recorded by the Geological Survey of Northern Ireland (GSNI) and the Geological Survey of Ireland (GSI) (Legg et al., 1985).

\section{Data mapping}

The soil geochemical and field observational data were entered into a GIS, ESRI ${ }^{\oplus}$ ArcGIS v.10. Maps showing the concentration and distribution of metals were generated using the ArcGIS Inverse Distance Weighting (IDW) interpolation function with a grid cell size of $250 \mathrm{~m}$, a fixed radius of $1500 \mathrm{~m}$ and a power value of 2 . Grids were produced using the Spatial Analyst tool, while the parameters of gridding were based on the methods of the UK G-BASE geochemical survey programme (Johnson et al., 2005). The geochemical data were classified according to the percentiles (5th, 10th, 25th, 50th, 75th, 90th, 95th and 99th) of the data distribution using a gradational colour scheme.

\section{MAPPING THE NATURAL BACKGROUND AND ANTHROPOGENIC COMPONENT}

\section{Geological background}

Concentrations of metals with anthropogenic origins must be distinguished from those of geogenic origin. Using the methods of Ridgway et al. (2003) and Lass-Evans (2013), we modelled the geological background soil geochemical signature for each sub-catchment by considering the different geological lithologies of the study area in the GIS. These modelled geological background signatures were then compared to the observed sub-catchment signatures in order to distinguish whether elevated soil metal concentrations were of anthropogenic or of natural origin.

The observed geochemical signatures for each sub-catchment were calculated by taking the average concentrations from all soil samples within each of the 31 sub-catchment boundaries. The geological background signature was modelled in $\mathrm{ArcGIS}^{\bullet}$ as follows:

- the areal extents (in \%) of the different geological lithologies in each sub-catchment were computed;

- soil samples within urban areas (e.g. samples that lie within defined urban areas on the current topographic map of Northern Ireland and the Republic of Ireland $(1: 250,000))$ or that might contain known sources of contamination were excluded from the model;

- the average element concentrations of the remaining soil samples were calculated over each lithology, and then combined on a weighted basis, according to the percentage that each lithology occupied in each sub-catchment. 
To compare the observed geochemical signature with the modelled geological background signature, the data were interpreted with the help of spidergrams. Element values (reported in $\mathrm{wt} \%$ ) were converted into $\mathrm{mg} \mathrm{kg}^{-1}(\mathrm{ppm})$ values; and elements were normalised to the upper continental crust (UCC) (Wedepohl, 1995). These multi-element plots have the advantage that elements with widely different concentrations can be viewed on a single diagram and that the pattern of variations can be compared, even if absolute concentrations are different.

\section{Enrichment factors}

To quantify the anthropogenic contribution to metal concentrations in the Derry-Londonderry soil samples, enrichment factors (EFs) for each sub-catchment were calculated by using the following equation (Kuusisto-Hjort and Hjort, 2013):

$$
\left.\mathrm{EF}=[(\text { Metal })] \_ \text {sample/[(Metal) }\right] \_ \text {baseline }
$$

where $[($ Metal) $]$ _sample is the average soil metal concentration in the sub-catchments (observed geochemical signature) and [(Metal)]_baseline is the average soil metal concentration of the modelled geological background.

Heavy metal enrichments were classified as no enrichment $(\mathrm{EF} \leq 1)$, minor enrichment $(1<\mathrm{EF} \leq 3)$, moderate enrichment $(\mathrm{EF} \leq 5)$, moderately severe enrichment $(5<\mathrm{EF} \leq 10)$, severe enrichment $(10<\mathrm{EF} \leq 25)$, very severe enrichment $(25<\mathrm{EF} \leq 50)$ and extremely severe enrichment $(\mathrm{EF}>50)$ (Birch and Davies, 2003).

\section{Distribution OF METALS IN SOILS}

Distribution maps showing the concentrations of metals in soils are given in Fig. 24.5 for the metals that are most likely associated with anthropogenic activities: arsenic (As), chromium $(\mathrm{Cr})$, molybdenum $(\mathrm{Mo})$, antimony $(\mathrm{Sb})$, copper $(\mathrm{Cu})$, nickel $(\mathrm{Ni})$, cadmium $(\mathrm{Cd})$, lead $(\mathrm{Pb})$, tin $(\mathrm{Sn})$, cobalt $(\mathrm{Co})$, mercury $(\mathrm{Hg})$, zinc $(\mathrm{Zn})$.

A brief overview is given below, but it was beyond the scope of this study to analyse the element distribution patterns in great detail; it is recommended that further investigations be carried out to relate heavy metal concentrations to parent material or soil formation processes. In general, the soils underlain by the Southern Highland Group in the Republic of Ireland west of Derry-Londonderry have higher $\mathrm{Co}, \mathrm{Cr}, \mathrm{Cu}$ and $\mathrm{Ni}$ concentrations than the Dart and Claudy Formations of the Southern Highland Group in Northern Ireland. The maps of these elements show similar patterns, so it is likely that their concentrations in the study area are mainly controlled by their parent material.

The soils underlain by the Southern Highland Group in the Republic of Ireland have low $\mathrm{Hg}, \mathrm{Pb}, \mathrm{Sb}$ and $\mathrm{Sn}$ concentrations, probably also associated with their parental material. In contrast, in Northern Ireland, $\mathrm{Hg}, \mathrm{Pb}, \mathrm{Sb}$ and $\mathrm{Sn}$ concentrations are elevated over the Dart Formation of the Southern Highland Group. This area corresponds to the upland
Figure 24.5. (a) Antimony, (b) arsenic, (c) cadmium, (d) chromium, (e) cobalt, (f) copper, (g) lead, (h) mercury, (i) molybdenum, (j) nickel, (k) tin and (l) zinc distribution in topsoil samples within the study area. 

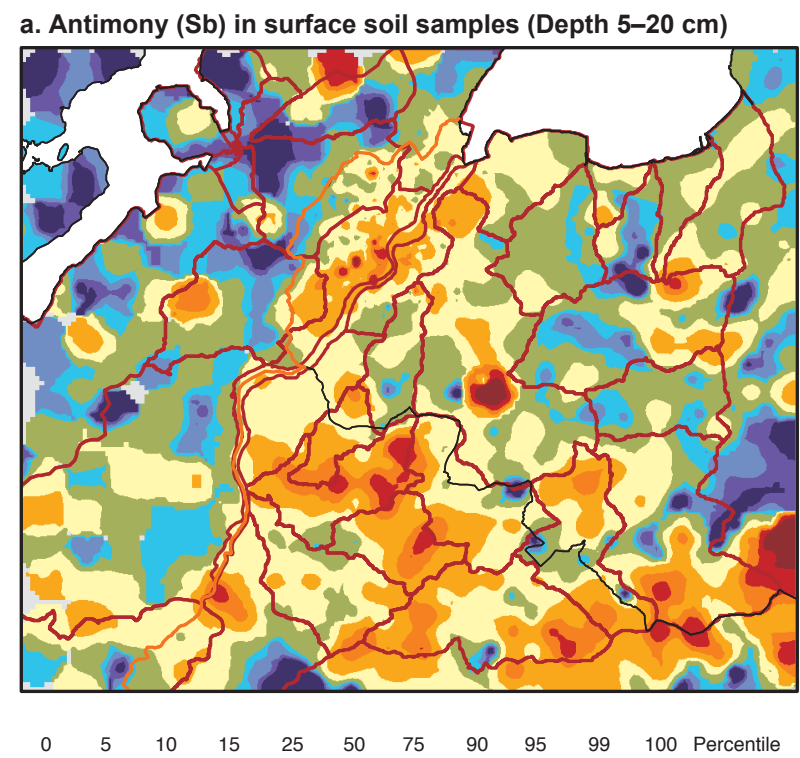

$\begin{array}{llllllllllll}0.0 & 0.14 & 0.16 & 0.19 & 0.22 & 0.30 & 0.46 & 0.74 & 0.96 & 1.42 & 5.4 & \mathrm{mg} \mathrm{kg}^{-1}\end{array}$

\section{c. Cadmium (Cd) in surface soil samples (Depth 5-20 cm)}

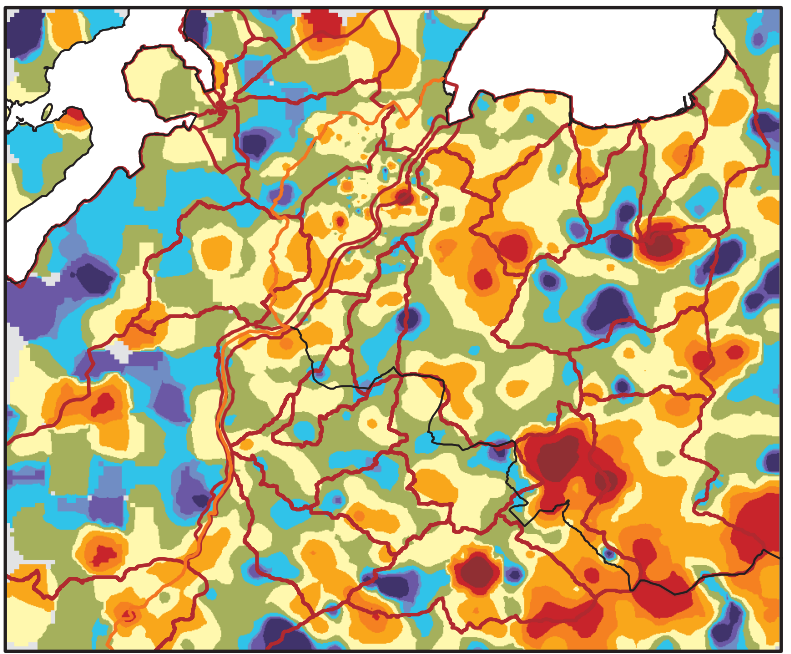

$\begin{array}{llllllllllll}0 & 5 & 10 & 15 & 25 & 50 & 75 & 90 & 95 & 99 & 100 & \text { Percentile }\end{array}$

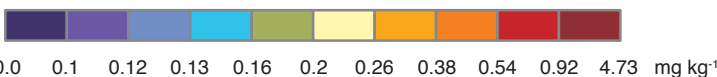

b. Arsenic (As) in surface soil samples (Depth 5-20 cm)

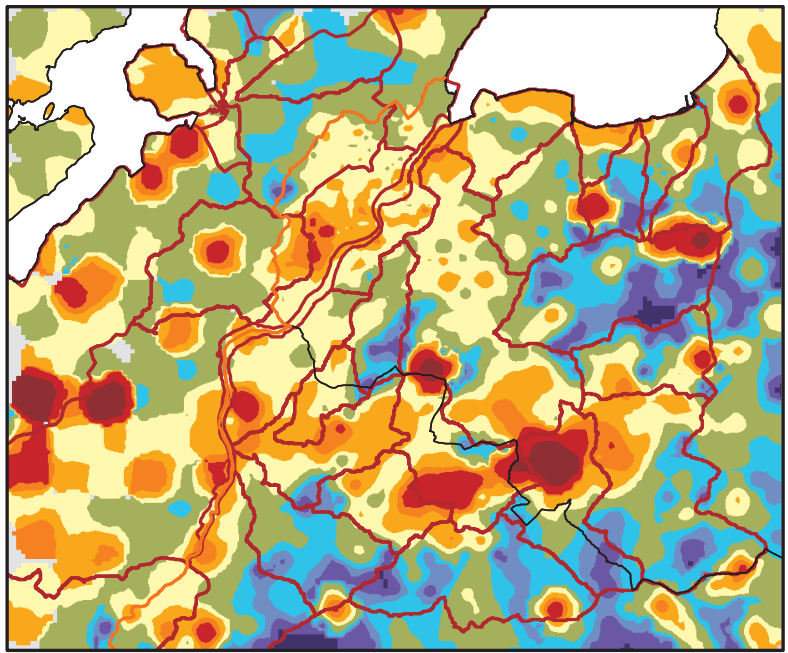

$\begin{array}{llllllllllll}0 & 5 & 10 & 15 & 25 & 50 & 75 & 90 & 95 & 99 & 100 & \text { Percentile }\end{array}$

$\begin{array}{lllllllllll}0.0 & 0.5 & 1.1 & 2.0 & 3.4 & 6.0 & 9.1 & 13.9 & 19.0 & 48.9 & 163.8 \\ \mathrm{mg} \mathrm{kg}^{-1}\end{array}$

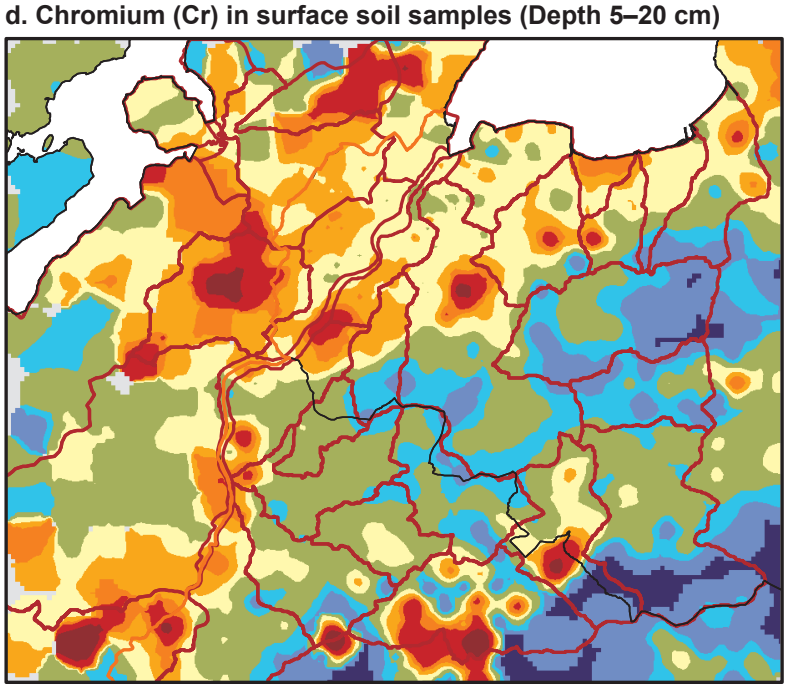

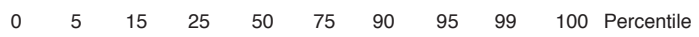

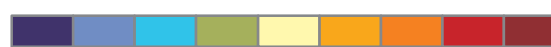

$\begin{array}{llllllllll}0.0 & 0.5 & 6.0 & 12.0 & 22.0 & 31.0 & 40.0 & 49.0 & 78.0 & 140.0 \\ \mathrm{mg} \mathrm{kg}^{-1}\end{array}$ 
Lass-Evans

e. Cobalt (Co) in surface soil samples (Depth $5-20 \mathrm{~cm}$ )

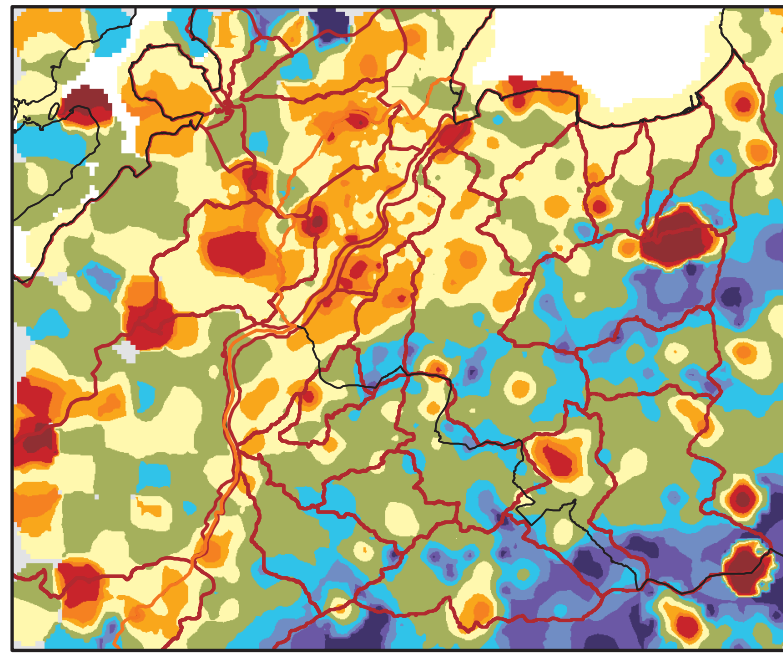

$\begin{array}{llllllllllll}0 & 5 & 10 & 15 & 25 & 50 & 75 & 90 & 95 & 99 & 100 & \text { Percentile }\end{array}$

$\begin{array}{lllllllllll}0.0 & 0.9 & 1.4 & 2.4 & 4.3 & 8.0 & 12.0 & 15.0 & 18.0 & 31.0 & 150.0 \mathrm{mg} \mathrm{kg}^{-1}\end{array}$

g. Lead $(\mathrm{Pb})$ in surface soil samples (Depth $5-20 \mathrm{~cm}$ )

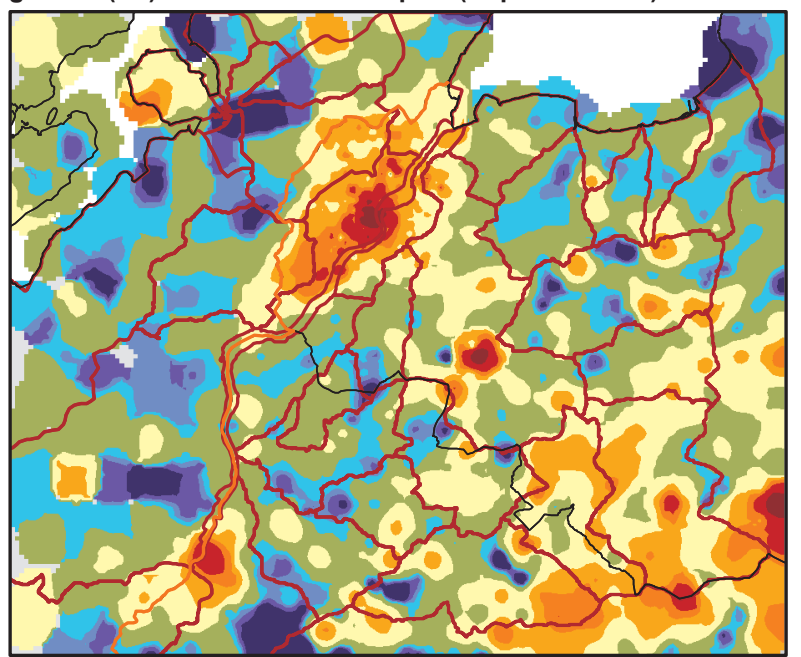

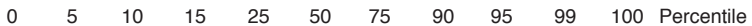

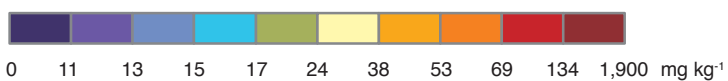

f. Copper $(\mathrm{Cu})$ in surface soil samples (Depth $5-20 \mathrm{~cm}$ )

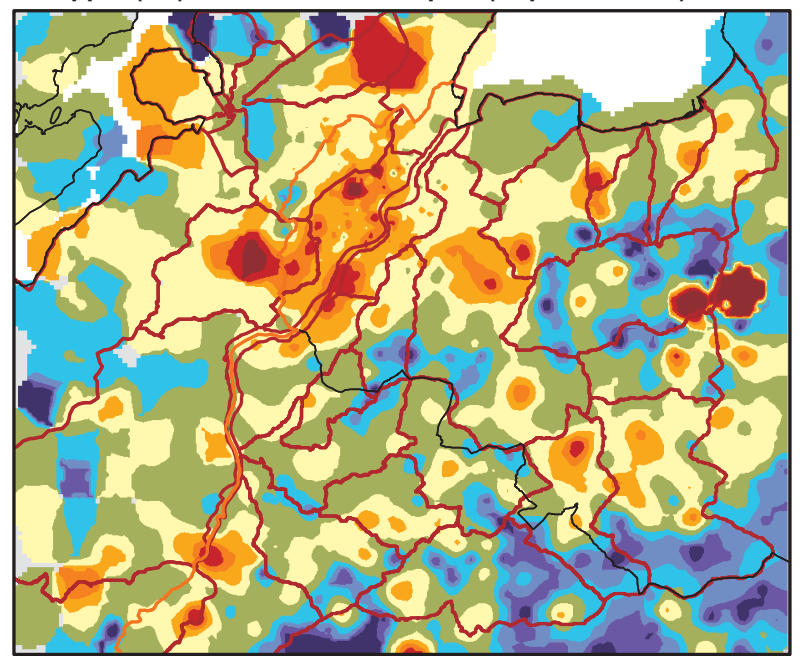

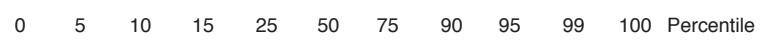

$\begin{array}{llllllllllll}0 & 6 & 7 & 10 & 16 & 25 & 34 & 43 & 51 & 71 & 635 & \mathrm{mg} \mathrm{kg}^{-1}\end{array}$ h. Mercury $(\mathrm{Hg})$ in surface soil samples (Depth $5-20 \mathrm{~cm}$ )

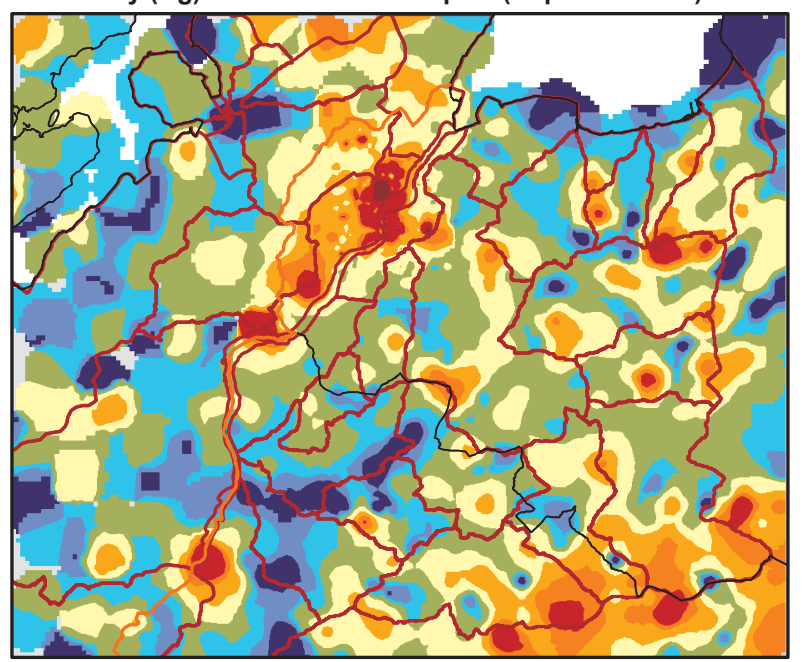

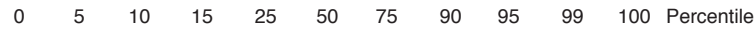

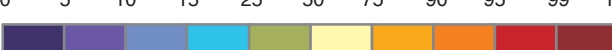

$\begin{array}{llllllllllll}0 & 25 & 30 & 33 & 51 & 56 & 75 & 95 & 112 & 176 & 548 & \mathrm{mg} \mathrm{kg}^{-1}\end{array}$ 
i. Molybdenum (Mo) in surface soil samples (Depth 5-20 cm)

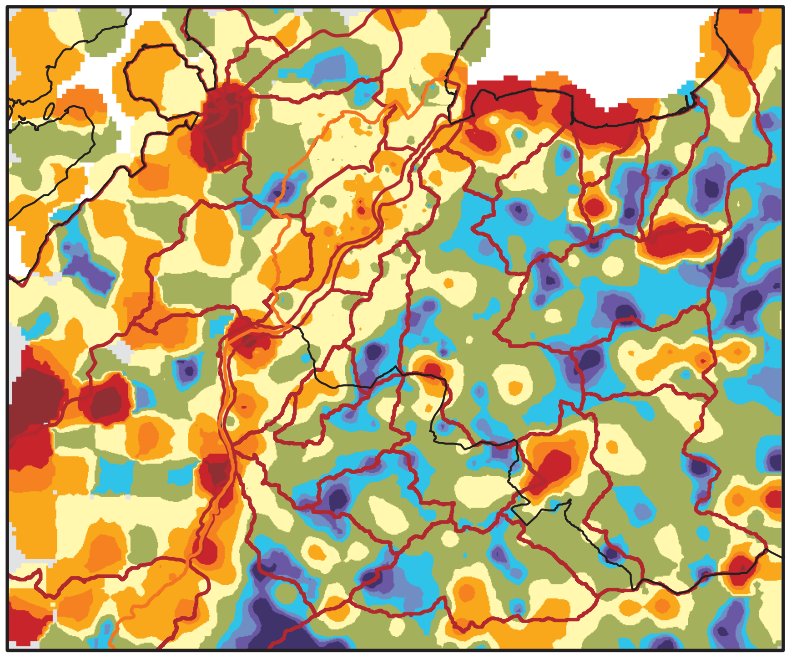

$\begin{array}{llllllllllll}0 & 5 & 10 & 15 & 25 & 50 & 75 & 90 & 95 & 99 & 100 & \text { Percentile }\end{array}$

\begin{tabular}{lllllllllllll}
\hline 0 & 0.23 & 0.28 & 0.32 & 0.39 & 0.56 & 0.78 & 1.13 & 1.49 & 3.06 & 12 & $\mathrm{mg} \mathrm{kg}^{-1}$
\end{tabular}

k. Tin (Sn) in surface soil samples (Depth $5-20 \mathrm{~cm}$ )

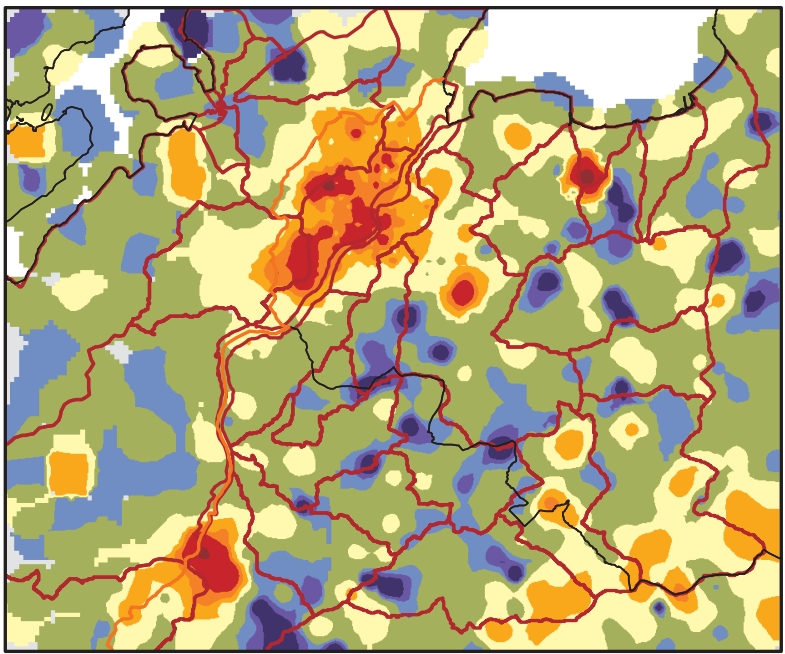

$\begin{array}{lllllllllll}0 & 5 & 10 & 15 & 50 & 75 & 90 & 95 & 99 & 100 & \text { Percentile }\end{array}$

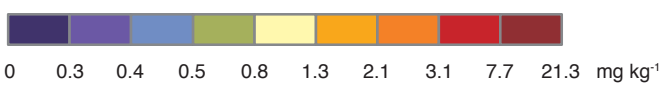

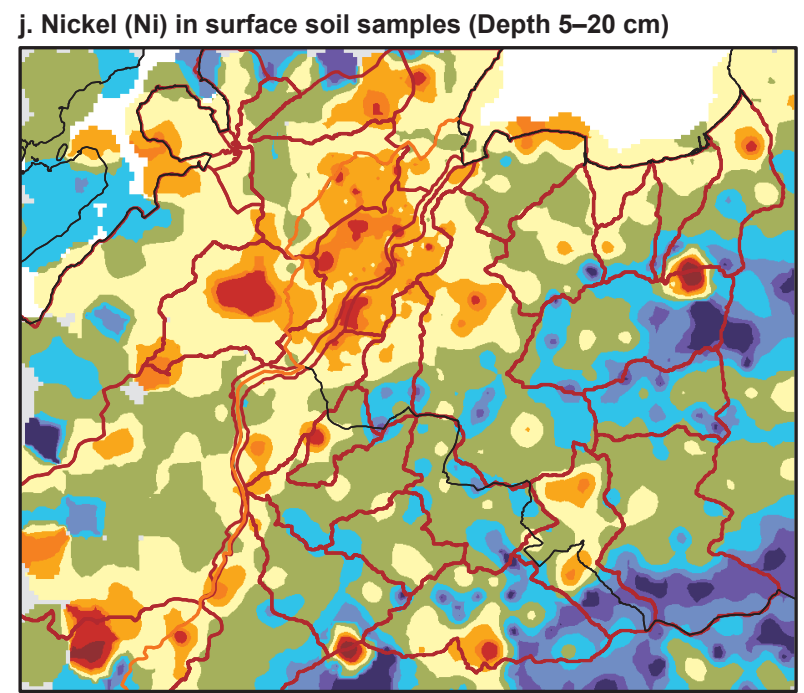

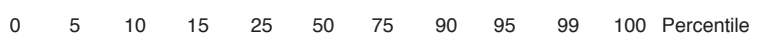
\begin{tabular}{lllllllllllll}
\hline & & & & & & & & & & & \\
0 & 3.1 & 3.9 & 5.9 & 9.7 & 15.8 & 23.8 & 30.6 & 34.6 & 49.3 & 76.7 & $\mathrm{mg} \mathrm{kg}^{-1}$
\end{tabular}

I. Zinc $(\mathrm{Zn})$ in surface soil samples (Depth $5-20 \mathrm{~cm}$ )
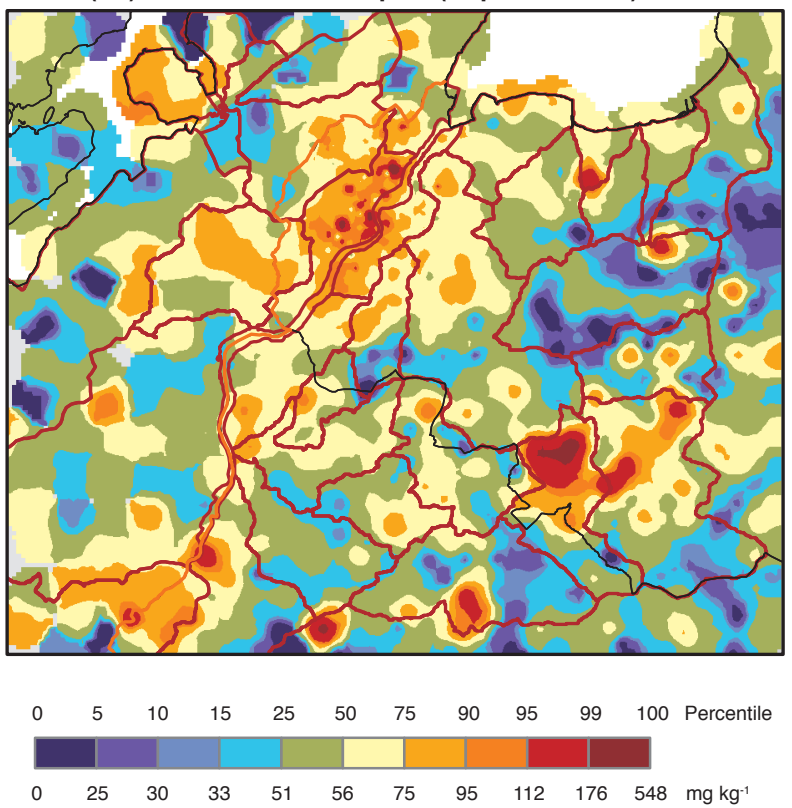


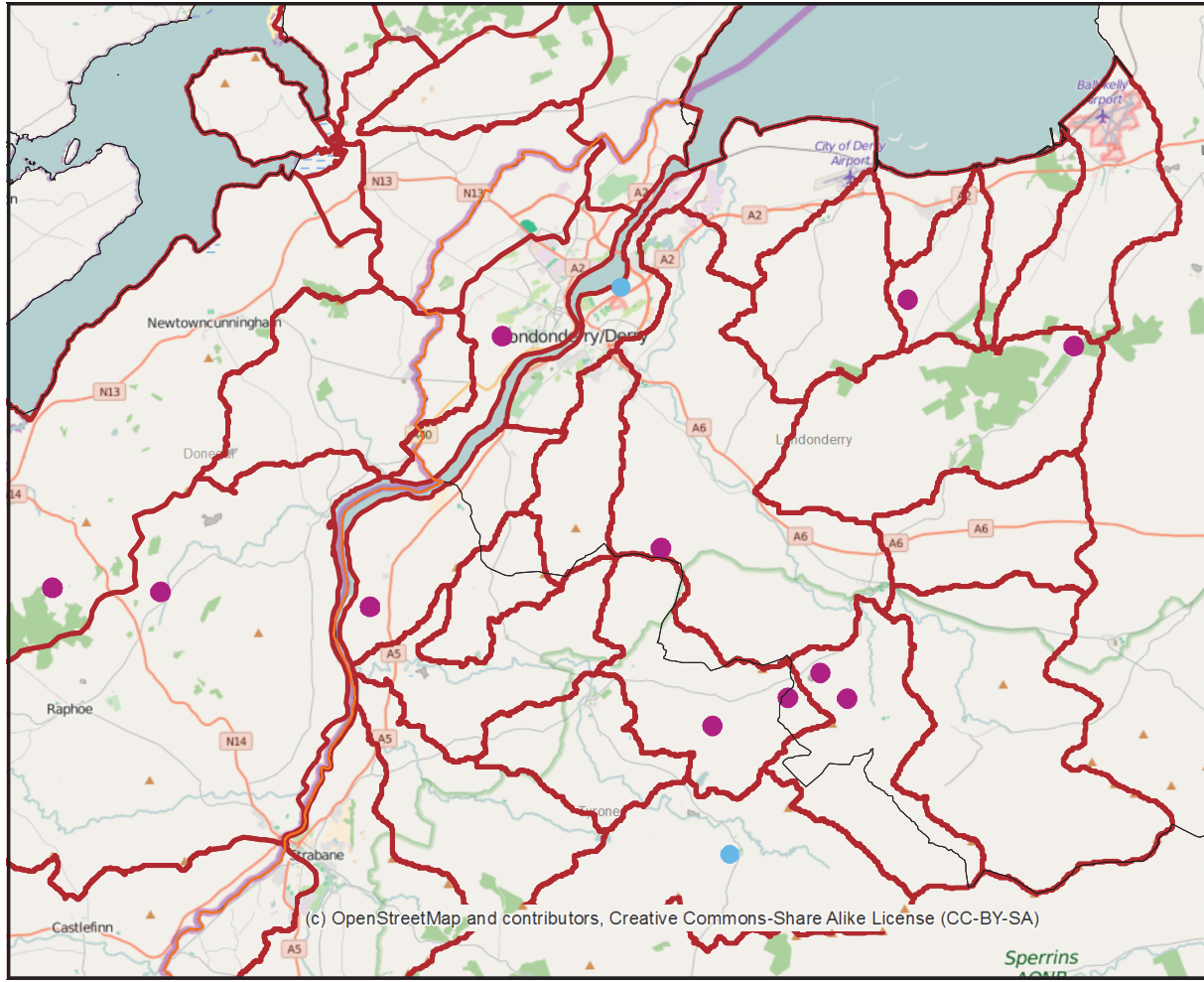

peaty soils of the Sperrin Mountains, so it is possible that these higher concentrations could be the result of atmospheric deposition due to higher rainfall, or to adsorption on peat in a reducing environment, or a combination of the two.

Elevated concentrations of $\mathrm{As}, \mathrm{Cd}, \mathrm{Cu}, \mathrm{Pb}, \mathrm{Sb}$ and $\mathrm{Zn}$ at sporadic locations over the Dalradian Supergroup could also be the result of natural mineralisation. Gold mineralisation with associated $\mathrm{Fe}, \mathrm{Pb}$ and $\mathrm{Zn}$ sulphides and other elements in minor concentrations is common in the Sperrin Mountains. Alluvial gold occurrences are common across north-west County Derry-Londonderry, which may imply as yet undetected mineralisation. Quartz-calcite vein mineralisation containing $\mathrm{Pb}$ and $\mathrm{Cu}$, with the potential for associated precious metals, occurs at a number of locations within the Precambrian-age metamorphic rocks in County Derry-Londonderry (Pitfield et al., 2012). However, most of the known mineral occurrences (Fig. 24.4) seem not to have an effect on soil quality in the study area, but some localised mineralisation near sampling points might have caused enhanced metal concentrations. For example, gold mineralisation in the sub-catchment Burn Dennet Lower may contribute to elevated $\mathrm{As}$ and $\mathrm{Sb}$ concentrations, while $\mathrm{Cu}$ and $\mathrm{Pb}$ mineralisation might have had caused enhanced $\mathrm{As}, \mathrm{Cd}, \mathrm{Cu}, \mathrm{Sb}$ and $\mathrm{Pb}$ concentrations in the area around Strabane. However, $\mathrm{Co}, \mathrm{Hg}, \mathrm{Mo}, \mathrm{Ni}$ and $\mathrm{Sn}$ concentrations are also enhanced around the urban area of Strabane, suggesting that anthropogenic activities might also have had an impact on soil quality locally.

\section{Exceeding UK Soil Guidelines Values (SGVs)}

(given in $\mathrm{mg} \mathrm{kg}^{-1}$ )

As $>32^{1}$

$\mathrm{Cd}>1.8^{2}$

Sub-catchments
UK Human CLEA Soil Guideline - residential (2011) ${ }^{2}$ UK Human CLEA Soil Guideline - allotment (2011)

\begin{tabular}{lll}
0 & $2.5 \quad 5$ \\
\hline
\end{tabular} $10 \mathrm{~km}$
Figure 24.6. Arsenic and cadmium distribution with respect to UK CLEA contaminated land SGVs.

Figure 24.7. Example spidergrams from a subcatchment where no anthropogenic sources are known (Burn Dennet Upper) and seven urban sub-catchments, where anthropogenic activities have an impact on soil quality. 


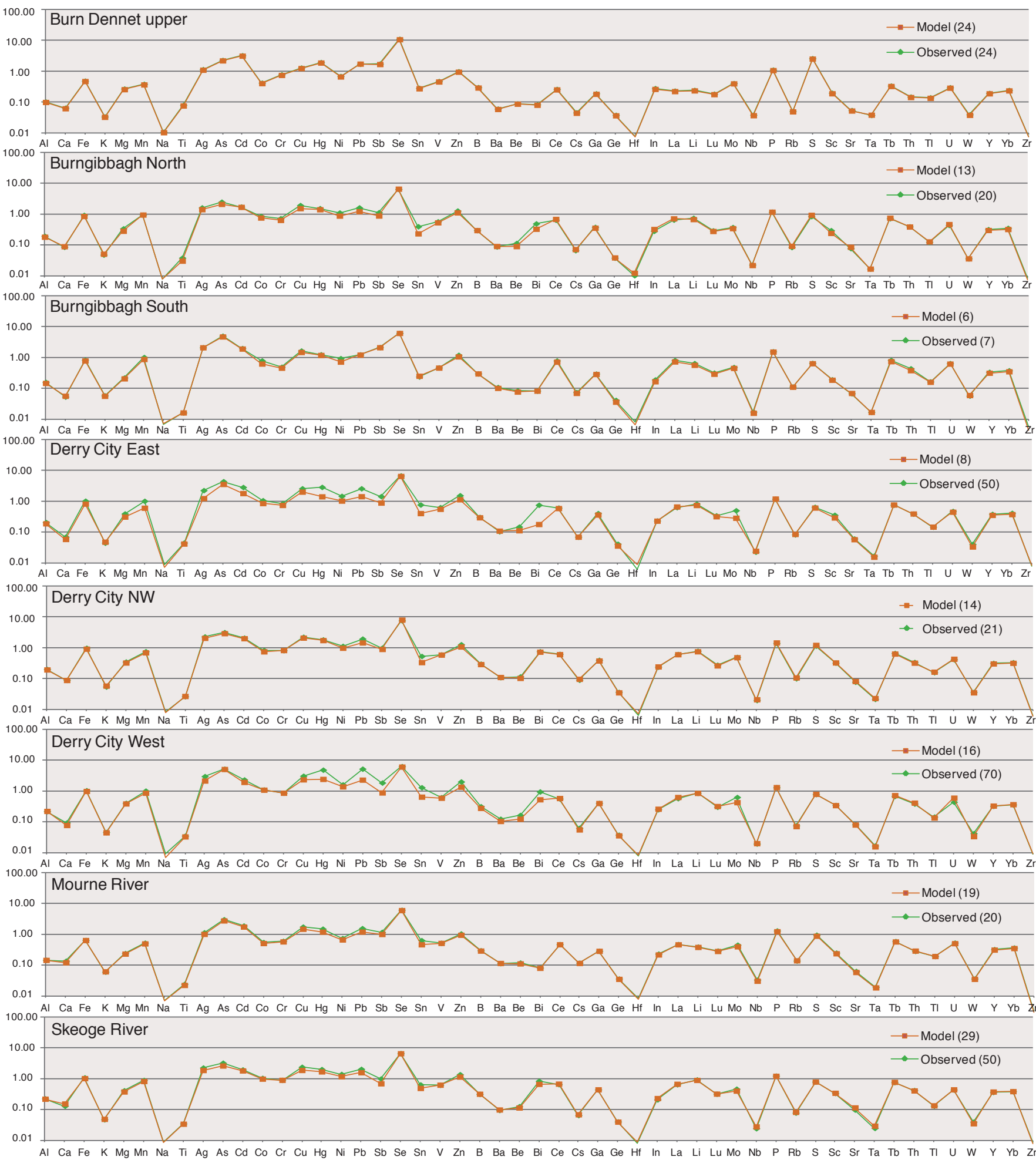


Elevated element concentrations in the urban area of Derry-Londonderry compared to the surrounding rural areas are seen for $\mathrm{Cu}, \mathrm{Hg}, \mathrm{Ni}, \mathrm{Pb}, \mathrm{Sb}$ and $\mathrm{Sn}$. Highest concentrations of $\mathrm{Pb}\left(1900 \mathrm{mg} \mathrm{kg}^{-1}\right), \mathrm{Hg}\left(7 \mathrm{mg} \mathrm{kg}^{-1}\right), \mathrm{Sn}\left(21 \mathrm{mg} \mathrm{kg}^{-1}\right)$ and $\mathrm{Zn}\left(548 \mathrm{mg} \mathrm{kg}^{-1}\right)$ occur in the Derry City West sub-catchment, while the highest concentration of Cd $\left(4.7 \mathrm{mg} \mathrm{kg}^{-1}\right)$ occurs in the Derry City East sub-catchment. Lead and $\mathrm{Hg}$ concentrations display zonation patterns with elevated element concentrations in the inner city that gradually decrease towards outer city areas.

\section{Quantifying soil quality}

Table 24.1 summarises the only inorganic UK CLEA SGVs published to date. In the study area, 11 samples exceeded the SGV for As ( $>32 \mathrm{mg} \mathrm{kg}^{-1}$; residential land use type) and two samples exceeded the SGV for Cd (>1.8 $\mathrm{mg} \mathrm{kg}^{-1}$; allotment land use type) (Fig. 24.6). None of the soil samples in the study area exceeded the three other published SGVs, for $\mathrm{Hg}$, Ni or Se. In the Derry-Londonderry urban area only two samples, both from visibly contaminated sites, exceeded the guideline values. Derry-Londonderry has relatively low metal concentrations compared to other cities, such as Belfast (Nice, 2010) and Glasgow (Fordyce et al., 2012). For example, in Belfast, 15 and 45 samples exceeded the SGV for As and Ni respectively, while in Glasgow 74 samples exceeded the SGV for As and 654 samples exceeded the SGV for Ni. In Glasgow, 78 samples also exceeded the former UK CLEA residential/allotment SGVs of $1 \mathrm{mg} \mathrm{kg}^{-1}$ for Cd (Fordyce et al., 2012). The samples exceeding the SGVs for As and Cd in the rural area of Derry-Londonderry do not correlate with known mineralisation occurrences, but not all of these may have been mapped so it is not certain whether these anomalies have geogenic or anthropogenic origins.

\section{Calculating the geological background}

To assess anthropogenic impacts on soil quality for each sub-catchment in the study area, the modelled geological background signatures were compared to the observed signatures for each element by plotting these on spiderplots (Reimann et al., 2008). The $y$-axis on these plots is a ratio of the elemental averages determined here divided by the UCC values (Wedepohl, 1995).

In rural sub-catchments, where no anthropogenic impacts are known, the observed signatures and the modelled geological background signatures follow the same patterns in the spiderplots, suggesting that the soil composition is largely determined by the underlying rock types. An example of such a rural catchment is the Burn Dennet Upper (Fig. 24.7a).

In an urban environment, elements most likely associated with anthropogenic activity (e.g. $\mathrm{Cd}, \mathrm{Cu}, \mathrm{Hg}, \mathrm{Ni}, \mathrm{Pb}, \mathrm{Sb}, \mathrm{Sn}, \mathrm{Zn}$ ) have higher values in the observed signature, compared to the modelled geological background, while the two signatures show close compatibility for elements not necessarily associated with urban activities. Examples of such urban sub-catchments are Burngibbagh North (Fig. 24.7b), Burngibbagh South 


\section{Metal enrichment due to human activities}

Enrichment Factors $>1.3$

for

Antimony $(\mathrm{Sb})$
Cadmium $(\mathrm{Cd})$
Copper $(\mathrm{Cu})$
Mercury $(\mathrm{Hg})$
Nickel $(\mathrm{Ni})$
Lead $(\mathrm{Pb})$
Silver $(\mathrm{Ag})$
Tin $(\mathrm{Sn})$
Zinc $(\mathrm{Zn})$
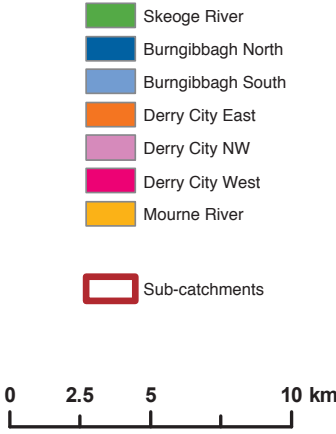

Figure 24.8. Sub-catchments where soil samples are enriched in metals ( $\mathrm{Ag}, \mathrm{Cd}, \mathrm{Cu}, \mathrm{Hg}$,

$\mathrm{Ni}, \mathrm{Pb}, \mathrm{Sb}, \mathrm{Sn}, \mathrm{Zn})$ more than 1.3 times the geological background as a consequence of human activities.

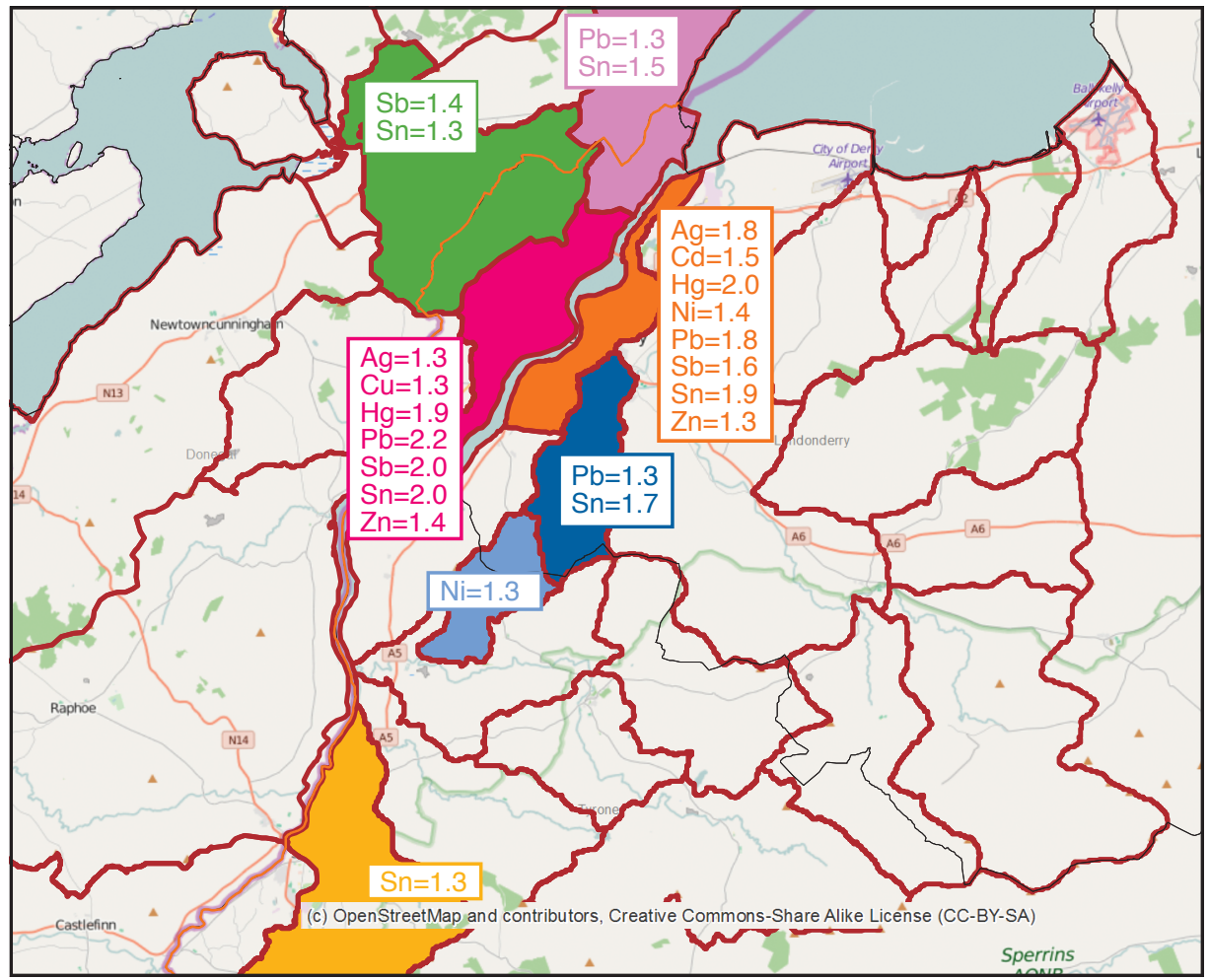

(Fig. 24.7c), Derry City East (Fig. 24.7d), Derry City NW (Fig. 24.7e), Derry City West (Fig. 24.7f), Mourne River (Fig. 24.7g) and Skeoge River (Fig. 24.7h).

\section{Enrichment factors}

In central Derry-Londonderry (Derry City East and Derry City West sub-catchments), $\mathrm{Ag}, \mathrm{Hg}, \mathrm{Pb}, \mathrm{Sb}$ and $\mathrm{Sn}$ are enriched by at least 1.5 times the natural background, while other elements, such as $\mathrm{Cd}, \mathrm{Cu}, \mathrm{Ni}$ and $\mathrm{Zn}$, have EFs between 1.3 and 1.5 in the urban area (Fig. 24.8). The outskirts of Derry-Londonderry show slight enrichments of $\mathrm{Pb}$ and $\mathrm{Sn}$ in the Derry City NW (EFs: $\mathrm{Pb}=1.3 ; \mathrm{Sn}=1.5$ ) and Burngibbagh North (EFs: $\mathrm{Pb}=$ $1.3 ; \mathrm{Sn}=1.7)$ sub-catchments and of $\mathrm{Sb}(\mathrm{EF}=1.4)$ and $\mathrm{Sn}(\mathrm{EF}=1.3)$ in the Skeoge River sub-catchment. The Burngibbagh South sub-catchment has a slight enrichment of Ni (EF =1.3), while the Mourne River sub-catchment (which includes the urban area of Strabane) in the southern part of the study area has a slight enrichment of $\mathrm{Sn}(\mathrm{EF}=1.3)$. Both the enrichment map (Fig. 24.8) and the distribution maps of Cu (Fig. 24.5f), $\mathrm{Hg}$ (Fig. 24.5h), $\mathrm{Ni}$ (Fig. 24.5j), Pb (Fig. 24.5g), Sb (Fig. 24.5a) and Sn (Fig. 24.5k) show elevated element concentrations and enrichments compared to the geological background in the urban area of Derry-Londonderry. As the enrichment map only takes account of enhancement of these elements due to human activities, $\mathrm{Cu}, \mathrm{Hg}, \mathrm{Ni}, \mathrm{Pb}, \mathrm{Sb}$ and $\mathrm{Sn}$ present in the urban soils in central Derry-Londonderry are likely of anthropogenic origin. 
Possible present-day sources of anthropogenic contamination in the affected sub-catchments are summarised in Table 24.2 on OSI maps. Specific possible sources of contamination in Derry-Londonderry are likely to be industry, a coal depot and sewage works. In addition, many urban activities act as sources of heavy metals to the environment, including buildings, households, waste deposal and surface run-off from road traffic and manufacturing industries. Atmospheric contamination from vehicle emissions and the burning of fossil fuels can also lead to metal accumulation in the urban environment (Fordyce et al., 2005, 2012; Johnson and Ander, 2008; Wong et al., 2006). Historical maps (around 1900) were available for some parts of Northern Ireland. Possible sources of heavy metal contamination in the Derry City East sub-catchment include a factory, a station, a hospital and railways, while brick works, engineering works, factories, gas works, mills, railways, a quarry and station were present in the Derry City West sub-catchment. However, compared to other cities, such as Dublin (Glennon et al., 2014), Belfast (Nice, 2010) or Glasgow (Fordyce et al., 2012), Derry-Londonderry was not heavily industrialised. Median concentrations of $\mathrm{As}, \mathrm{Cu}, \mathrm{Pb}, \mathrm{Sb}$ and $\mathrm{Zn}$ in Derry-Londonderry are half or less of the concentrations recorded in Dublin, Belfast and Glasgow. Overall, soil sub-catchment EFs in Derry-Londonderry and the surrounding cross-border area are no greater than 2.2, which is classified as minor enrichment (Birch and Davies, 2003).

\section{Conclusions}

To assess potential anthropogenic impacts on soil quality in Derry-Londonderry and the surrounding cross-border area, this project modelled the soil geochemistry for the geological background of the lower River Foyle catchment. We have been able to distinguish high metal concentrations of natural origin from those affected by human activities.

Soil quality was assessed by determining the samples that exceeded the UK CLEA contaminated land soil guideline values. Eleven samples exceeded the soil guideline value for arsenic and two samples exceeded the soil guideline value for cadmium. Only two of these 13 samples were in urban areas. On the basis of this study, it appears that the higher element concentrations in the rural area are caused by natural metal enhancements rather than anthropogenic contamination.

These results show that soil quality in the rural sub-catchments is good and mainly determined by the underlying geology. The urban area of Derry-Londonderry shows metal enhancements due to anthropogenic activities, and the main sources for this contamination are likely to be buildings, households and waste disposal, surface run-off from road traffic and manufacturing industries, coal disposal and sewage works. In the urban environment, the elements studied are enriched by a magnitude of at least 1.3. However, as their EFs do not exceed 3.0, their enrichment can be classified as minor.

The results of this study should help to inform future land-use management strategies. 


\section{ACKNOWLEDGEMENTS}

This chapter is published with the permission of the Executive Director of the British Geological Survey (NERC).

\section{REFERENCES}

Ander, E.L, Johnson, C.C., Cave, M.R., Palumbo-Roe, B., Nathanail, C.P. and Lark, R.M., 2013 'Methodology for the determination of normal background concentrations of contaminants in English soil', Science of the Total Environment, 454-5, 604-18. Available at http://nora.nerc.ac.uk/501486/. http://dx.doi.org/10.1016/j.scitotenv.2013.03.005.

Birch, G. and Davies, K., 2003 'A scheme for assessing human impact and sediment quality in coastal waterways.' Coastal GIS 2003: An integrated approach to Australian issues. Wollongong Papers on Marine Policy, 14, 371-80.

British Standards Institution, 2011 'Soil Quality: Guidance on the Determination of Background Values'. BS EN ISO 19258:2011. London. BSI. Available at http://shop.bsigroup.com/.

Cooper, M.R. and Johnston, T.P., 2004 'Central Highlands (Grampian) Terrane - metamorphic basement', in W.I. Mitchell (ed.), The Geology of Northern Ireland: Our Natural Foundation. Second edition, 9-24. Belfast. Geological Survey of Northern Ireland.

Cruickshank, J.G., 1997 Soil and Environment: Northern Ireland. Belfast. Department of Agriculture Northern Ireland.

DEFRA and Environment Agency, 2004 Model Procedures for the Management of Land Contamination. Contaminated Land Report 11. Bristol. Environment Agency. Available at https://www.gov.uk/government/publications.

DEFRA, 2008 Guidance on the Legal Definition of Contaminated Land. London. Department of Environment, Food and Rural Affairs. Available at https://www.gov.uk/government/publications.

Doak, M., 2004 'Contaminated land and risk assessment: the basics. Necessary steps prior to remediation and development.' Proc. Annual Conference of the International Association of Hydrogeologists (Irish Group). Wexford. Environmental Protection Agency. Available at http://www.epa.ie/search/results.jsp\#.VoqeQlLOHYQ.

Environment Agency (EA), 2009a Using Soils Guideline Values. Science report SC050021/SGV introduction. Bristol. Environment Agency. Available at https://www.gov.uk/government/ publications.

Environment Agency (EA), 2009b Soil Guideline Values. Bristol. Environment Agency. Available at https://www.gov.uk/government/publications.

Environmental Protection Act Part IIA. 1990. Contaminated Land. London. HMSO.

Fordyce, F.M., Brown, S.E., Ander, E.L., Rawlins, B.G., O’Donnell, K.E., Lister, T.R. et al., 2005 'GSUE: urban geochemical mapping in Great Britain', Geochemistry: Exploration, Environment, Analysis, 5, 4, 325-36. Available at http://nora.nerc.ac.uk/883/. http://dx.doi.org/10.1144/1467-7873/05-069.

Fordyce, F.M., Nice, S.E., Lister, T.R., Ó Dochartaigh, B.É., Cooper, R., Allen, M. et al., 2012 Urban Soil Geochemistry of Glasgow - Main Report. British Geological Survey Open Report, OR/08/002. Keyworth, UK. Available at http://nora.nerc.ac.uk/18009/.

Geological Survey of Northern Ireland (GSNI), 1997 Northern Ireland - Solid Geology (second edition), 1:250,000 (map). Keyworth, UK. British Geological Survey.

Glennon, M.M., Harris, P., Ottesen, R.T., Scanlon, R.P. and O’Connor, P.J., 2014 'The Dublin SURGE Project: geochemical baseline for heavy metals in topsoils and spatial correlation with historical industry in Dublin, Ireland', Environmental Geochemistry and Health, 36, 2, 235-54.

Johnson, C.C. and Ander, E.L., 2008 'Urban geochemical mapping studies: how and why we do them', Environmental Geochemistry and Health, 30, 6, 511-30. Available at http://nora.nerc.ac.uk/4907/. http://dx.doi.org/10.1007/s10653-008-9189-2. 
Johnson, C.C. and Demetriades, A., 2011 'Urban geochemical mapping: A review of case studies in this volume', in C.C. Johnson et al. (eds), Mapping the Chemical Environment of Urban Areas. First edition. Chichester, UK. Wiley. Available at http://nora.nerc.ac.uk/16215/. http://dx.doi.org/10.1002/9780470670071.ch2.

Johnson, C.C., Ander, E.L., Cave, M.R. and Palumbo-Roe, B., 2012 Normal Background Concentrations (NBCs) of Contaminants in English Soils Final Project Report. British Geological Survey Commissioned Report, CR/12/035. Keyworth, UK. Available at http://nora.nerc.ac.uk/19946/.

Johnson, C.C., Breward, N., Ander, E.L. and Ault, L., 2005 'G-BASE: baseline geochemical mapping of Great Britain and Northern Ireland', Geochemistry: Exploration, Environment, Analysis, 5, 347-57. Available at http://nora.nerc.ac.uk/884/. http://dx.doi.org/10.1144/1467-7873/05-070.

Knights, K.V., 2007 A Report on the Tellus Urban Field Campaigns of Belfast Metropolitan Areas and Londonderry, 2006. British Geological Survey Commissioned Report 07/006N. Keyworth, UK. Available at http://nora.nerc.ac.uk/7486/.

Kuusisto-Hjort, P. and Hjort, J., 2013 'Land use impacts on trace metal concentrations of suburban stream sediments in the Helsinki region, Finland', Science of the Total Environment, 456-7, 222-30.

Lass-Evans, S., 2013 Mining Impact on Stream Sediment Quality in County Antrim, Northern Ireland. British Geological Survey Commissioned Report, CR/13/130. Keyworth, UK. Available at http://nora.nerc.ac.uk/504456/.

Legg, I.C., Pyne, J.F., Nolan, C., McArdle, P., Flegg, A.M. and O’Connor, P.J., 1985 Mineral Localities in the Dalradian and Associated Igneous Rocks of County Donegal, Republic of Ireland and of Northern Ireland. Geological Survey of Ireland Report Series RS 85/3. Dublin.

Matschullat, J., Ottenstein, R. and Reimann, C., 2000 'Geochemical background - can we calculate it?', Environmental Geology, 39, 990-1000.

Mitchell, W.I., 2004 'Carboniferous', in W.I. Mitchell (ed.), The Geology of Northern Ireland: Our Natural Foundation. Second edition, 79-116. Belfast. Geological Survey of Northern Ireland.

Nice, S.E., 2010 Inorganic Soil Geochemical Baseline Data for the Urban Area of the Belfast Metropolitan Area, Northern Ireland. British Geological Survey Open Report, OR/08/021. Keyworth, UK. Available at http://nora.nerc.ac.uk/9599/.

Pitfield, P.E.J., Mankelow, J.M., Cooper, M.R., Shaw, R.A., Lusty, P.A., Cameron, D.G. and Linley, K.A. 2012 County Londonderry: Mineral Resource Map of Northern Ireland. British Geological Survey Open Report OR/12/016. Keyworth, UK. Available at http://nora.nerc.ac.uk/18980/.

Reimann, C., Filzmoser, P., Garrett, R.G. and Dutter, R., 2008. Statistical Data Analysis Explained. Chichester, UK. Wiley.

Reimann, C. and Garrett, R.G., 2005 'Geochemical background - concept and reality', Science of the Total Environment, 350, 12-27.

Ridgway, J.M., Breward, N., Langston, W.J., Lister, T.R., Rees, J.G. and Rowlatt, S.M., 2003 'Distinguishing between natural and anthropogenic sources of metals entering the Irish Sea', Applied Geochemistry, 18, 283-309. http://dx.doi.org/10.1016/S0883-2927(02)00126-9.

Wedepohl, K.H., 1995 'The composition of the continental crust', Geochimica et Cosmochimica Acta, 59, 1217-32.

Wong, C.S.C., Xiangdong, L. and Thorton, I., 2006 'Urban environmental geochemistry of trace elements', Environmental Pollution, 142, 1-16. 
Unearthed: impacts of the Tellus surveys of the north of Ireland

First published in 2016 by the

Royal Irish Academy

19 Dawson Street

Dublin 2

www.ria.ie

Copyright (C) 2016 Royal Irish Academy

ISBN: 978-1-908996-88-6

The articles in this book are open access and distributed under the terms of the Creative Commons Attribution 4.0 licence, which permits unrestricted use, distribution and reproduction in any medium, provided the original authors and source are credited. To view a copy of this licence, visit https://creativecommons.org/licenses/by/4.0/

Except where noted:

Geological mapping for Northern Ireland / Tellus data are provided by the Geological Survey of Northern Ireland.

Geological mapping for Ireland / Tellus Border data are provided by the Geological Survey of Ireland.

Topographic mapping for Northern Ireland is derived from Land and Propery Services Open Data and contains public sector information licensed under the Open Government Licence v3.0. (http://www.nationalarchives.gov.uk/doc/open-governmentlicence/version/3/).

Topographic mapping for Ireland is derived from Ordnance Survey of Ireland Open Data (https://creativecommons.org/licenses/by/4.0/legalcode).

While every effort has been made to contact and obtain permission from holders of copyright, if any involuntary infringement of copyright has occurred, sincere apologies are offered, and the owner of such copyright is requested to contact the publisher.

British Library Cataloguing-in-Publication Data. A catalogue record is available from the British Library.

Design: Alex Donald, Geological Survey of Northern Ireland.

Index: Brendan O'Brien.

Printed in Poland by L\&C Printing Group. 


\section{Table of Contents:}

\section{Prelim}

DOI: https://doi.org/10.7486/DRI.b851k323d

\section{Chapter 1}

The Tellus geosciences surveys of the north of Ireland: context, delivery and impacts

DOI: https://doi.org/10.7486/DRI.st74s528d

\section{Chapter 2}

The Tellus airborne geophysical surveys and results DOI: https://doi.org/10.7486/DRI.t148tx96z

\section{Chapter 3}

The Tellus geochemical surveys, results and applications

DOI: https://doi.org/10.7486/DRI.t722wq645

\section{Chapter 4}

Stakeholder engagement for regional geoscientific surveying: the Tellus Border communications campaign

DOI: https://doi.org/10.7486/DRI.w089fr763

\section{Chapter 5}

Mineral resources and Tellus: the essential balance DOI: https://doi.org/10.7486/DRI.wd37kb12s

\section{Chapter 6}

Gold exploration in the north of Ireland: new targets from the Tellus Projects

DOI: https://doi.org/10.7486/DRI.wh24m696v

\section{Chapter 7}

Using soil geochemistry to investigate gold and base metal distribution and dispersal in the glaciated north of Ireland

DOI: https://doi.org/10.7486/DRI.wm11n3806

\section{Chapter 8}

Critical metals for hightechnology applications: mineral exploration potential in the north of Ireland DOI: https://doi.org/10.7486/DRI.wp98p0649

\section{Chapter 9}

A natural laboratory for critical metals investigations in the Mourne Mountains granites

DOI: https://doi.org/10.7486/DRI.cc08ww45f

\section{Chapter 10}

Geothermal potential of granitic rocks of the Mourne Mountains

DOI: https://doi.org/10.7486/DRI.ff36jm09f

\section{Chapter 11}

Shape and intrusion history of the Late Caledonian

Newry Igneous Complex, Northern Ireland

DOI: https://doi.org/10.7486/DRI.2v248822m

\section{Chapter 12}

Using Tellus data to enhance targeting of volcanogenic massive sulphide mineralisation in the Tyrone Igneous Complex

DOI: https://doi.org/10.7486/DRI.5x226w262

\section{Chapter 13}

The geological significance of electrical conductivity anomalies of the Ordovician- Silurian Moffat Shale Group, Northern Ireland

DOI: https://doi.org/10.7486/DRI.6m31f4149

\section{Chapter 14}

Faults, intrusions and flood basalts: the Cenozoic structure of the north of Ireland

DOI: https://doi.org/10.7486/DRI.90205h306

\section{Chapter 15}

Information for agriculture from regional geochemical surveys: the example of soil $\mathrm{pH}$ in the Tellus and Tellus Border data

DOI: https://doi.org/10.7486/DRI.dv14c8060

\section{Chapter 16}

An ecohydrological investigation of wetlands in the border counties of Ireland: a framework for a holistic understanding of wetland systems DOI: https://doi.org/10.7486/DRI.hd775d90j 
Chapter 17

Assessing nutrient enrichment risk to groundwaterdependent ecosystems in the border counties of Ireland DOI: https://doi.org/10.7486/DRI.k356pk18j

\section{Chapter 18}

Mapping the terrestrial gamma radiation dose

DOI: https://doi.org/10.7486/DRI.k930rb86z

\section{Chapter 19}

Soils and their radiometric characteristics

DOI: https://doi.org/10.7486/DRI.mp495t62g

\section{Chapter 20}

Modelling in-house radon potential using Tellus data and geology to supplement inhouse radon measurements

DOI: https://doi.org/10.7486/DRI.ns06hm86z

\section{Chapter 21}

Determining geochemical threshold values from the Tellus data sets: the examples of zinc and iodine| DOI: https://doi.org/10.7486/DRI.r2087418g

\section{Chapter 22}

Identification of the geochemical signatures of diffuse pollution in the Tellus Border soil data set, using source apportionment

DOI: https://doi.org/10.7486/DRI.wh24m698d

\section{Chapter 23}

Stream sediment background concentrations in mineralised catchments in Northern Ireland: assessment of 'pressures' on water bodies in fulfilment of Water Framework Directive objectives DOI: https://doi.org/10.7486/DRI.x633tf86g

\section{Chapter 24}

Mapping metallic contamination of soils in the Lower Foyle catchment

DOI: https://doi.org/10.7486/DRI.9k42bv355

\section{Chapter 25}

Refining the human health risk assessment process in Northern Ireland through the use of oral bioaccessibility data

DOI: https://doi.org/10.7486/DRI.9p29cr199

\section{Chapter 26}

Combining environmental and medical data sets to explore potential associations between environmental factors and health: policy implications for human health risk assessments

DOI: https://doi.org/10.7486/DRI.9s16dn03n

\section{Chapter 27}

Mapping a waste disposal site using Tellus airborne geophysical data

DOI: https://doi.org/10.7486/DRI.9w03fh87q

\section{Chapter 28}

The use of aero-magnetics to enhance a numerical groundwater model of the Lagan Valley aquifer, Northern Ireland

DOI: https://doi.org/10.7486/DRI.9z90gd711

\section{Chapter 29}

Carbon sequestration in the soils of Northern Ireland: potential based on mineralogical controls DOI: https://doi.org/10.7486/DRI.b277h9556

\section{Chapter 30}

Spatial distribution of soil geochemistry in geoforensics DOI: https://doi.org/10.7486/DRI.b564j6392

\section{End matter}

DOI: https://doi.org/10.7486/DRI.bc38m007j 